\title{
A FIRST TIMER'S EXPERIENCE IN GRASSLANDS NATIONAL PARK
}

DARCY HENDERSON, 259 David Knight Crescent, Saskatoon, Saskatchewan. S7K 5L7

In September 1992, I took part in a field trip with the Integrated Resource Management students from Saskatchewan Institute of Applied Science and Technology (SIAST), Woodland Campus. The most memorable experience from the trip was the 24 hours we spent in Grasslands National Park, an area harbouring a great variety of wildlife, including many rare species, and with haunting landscapes and a fascinating local history.

Our accommodations were nylon tents in the Val Marie campground. First stop, the park office. A modest facility, it offered maps, auto-tour leaflets and fact sheets on the park's wildlife. As well, the local high school's (less than professionally produced) video on "Rattlesnake Safety" was surprisingly detailed and informative.

Our tour of the park with interpreter Florence Miller took us along the "Frenchman River Eco-Tour" route. Approaching from the north, we crossed a texas gate into the park. The first view of the valley was from the edge of the escarpment, where we stood amongst teepee rings and buffalo rubbing stones. Hundreds of metres below the Frenchman River was a long green snake of vegetation. Above the river and grassy plains were white clay slopes that led my eyes to the subtly coloured bands in the cliffs and hill sides. Erosion and time had wrinkled these surfaces that, from a distance, resemble furrowed bark. On the distant hilltops exposed rock of many kinds sparkled in the midday sun. Looking toward the southeast, I could see the many kilometres of coulees that dissect the uplands. Circling high above me was a lone Ferruginous Hawk that proceeded to fly into the valley.

Following the bird's lead, into the valley we drove. The only thing taller than the clumps of sagebrush (Artemisia cana) on the level plains were the trees and shrubs that grew along the river - a band of willows (Salix spp.), hawthorns (Cratageus spp.) and buffaloberry (Shepherdia argentea) - with the monotony broken only by the occasional poplar. I had to be sure not to blink or I might have missed the humble river. While crossing the short bridge, we spotted two Western Painted Turtles basking on the banks. Unfortunately, my camera lens and the turtles' patience were not long enough for a snapshot.

Stopping at the Larson ranch gave us a great opportunity to observe a herd of Pronghorn near by. Through 
the binoculars I could see a buck struggling to round up a harem. The does would crawl from one side of a ience to another. making it frustrating and dificult for the buck. Among the old grey imbers of the ranch builoings, a small Nuttall's Cottontail was spotred. Unlike the turtles, it quietly sat there allowing a few of us to get some close-up photos.

Down the road. the large Prairie Dog colony was hard to miss. As we crove. I first noticed what apoeared :0 me to be little volcanoes with ash spewing out oi them. Beside other mounds stood Prairie Dogs, as sentinels. batking out as soon as we stopped. Sitting on the remnants of an old corral was a Cooper's Hawk. also interested in the goings on of the ciminutive community. When I waked among the colony. I was interested to observe the Prairie Dogs behaviour. The animals vacated a distinct circular area directly around me. Beyond that. they would lie close to the ground at their burrow entrances. Sill iurther out. were Prairie Dogs standing. barking and jumping about. Waming their comrades of my presence. We soon left. leaving the creatures to continue their business as usual.

In the late afternoon. at the end of our guided iour. our Wildite Instructor Hemiton Greenwood led us on a hie to see a Prairie Rattesnake hibemaculum. It was a $5 \mathrm{~km}$ hike across the plains. past fields of cacti (Opunta sop. and Mamillaria soo.) sprintled with greasewood (Sarcobacrus vermiculatus). sagebrush and Creeping Junipei (Juniperus horizontalis). Aiter an hour. the six of us at the head of the group saw our first rattesnake. Now. I had seen rattlesnakes on :elevision and in zoos, but 1 had never heard one ratile up close. Believe me. it was unmistak- able. Yet. it was much louder and much more persistent that I had expected. At this point. we made sure to carry sticks and search the low lying juniper for snakes that might: also be in our path. Minutes later. We had ancther encounter, this tirne with an Eastern Yellow-bellied Racer. Two racers were seen that day one young animal and one adult. the la:ter just less that a meire long. These two racers represented approximately $2 \%$ of the Saskatchewan pooulation.

Once at the hibernaculum itseli. we saw perhaps hal a dozen ratiesnakes. The hibernaculum was noining unique, just an old box or covo:e den. Again we saw young snakes and adults. One di the aduth rettlers was nearly $2 \mathrm{~m}$ long. Other species such as Bull Snakes and Garter Snakes use inese hibemacula to wait out the winter. Apparenty there are several such sites in this area of the park.

By sundown we had retumed from the hike ravenously hungy for out meal at the Val Marie Hotel. The hotel itself is worth outing on a park tour itinerary. Unusual statues, photographs of "seven ioot long Bu" Snakes" and rodeo stars, as well as a beer with proprietor cowboy, Clift Olsen, are all musts.

After dinner. we went ior a crive through the park during the las: hours of light. We wanted to get a look at one of the 20 or more Swift. Foxes released just days earler. In the soace oi about $10 \mathrm{~km}$. we came across just fewer than 50 Pronghorn. Mule Deer and White-taled Deer. Most exciting, though, ware the four Swit Foxes spotted. Smal but iast. they maintaned a distance that required us to use oinoculars most oi the time. One animal was seen 
prowling around the Prairie Dog colony, sniffing at burrow entrances. This was a definite highlight of the trip, since Swift Foxes had not lived in the area for years. These were the first re-introduced by the Swift Fox Recovery program. Early the next morning, we started out on another 5 $\mathrm{km}$ hike, this time uphill, to the top of "70-mile butte." It was hard work climbing up over cobbles and gravel, past hogbacks and sandstone outcrops. Covering the sandstone were several different shades of lichen, which, when combined with the rust from the ironstone, created beautiful natural works of art. Lichens also covered the Bison horn that we found and turned over to park staff.
Almost at the top, we got an excellent view of a Golden Eagle's nest. Made up of a column of sticks about $5 \mathrm{~m}$ high and $2 \mathrm{~m}$ wide, it was obviously a venerable structure having been built over so many times. One of the students managed to climb into the nest and retrieve a number of well-weathered rodent skulls and various other bones. Once we arrived at the top of the butte, almost $170 \mathrm{~m}$ above the valley floor, the sun started to break through the clouds on the eastern horizon. The valley was filled with a haze of pale orange and yellow light. I could see south into Montana, northeast to Pinto Butte and, all around, a natural prairie wonderland.

All these cattle are of one color, namely brown, and it was a great marvel to see a white bull in such a multitude. Their form is so frightful that one can only infer that they are a mixture of different animals. The bulls and cows alike are humped, the curvature extending the whole length of the back and even over the shoulders. And although the entire body is covered with wool, on the hump, from the middle of the body to the head, the breast, and the forelegs, to just above the knee, the wool is much thicker, and so fine and soft that it could be spun and woven like that of Castilian sheep. It is a very savage animal, and is comparably larger than our cattle, although it looks small because of its short legs. Its hide is the thickness of that of our cattle, and the native indians are so expert in dressing the hides that they convert them into clothing. Don Juan de Onate. 1601. True account of the Expedition of Onate Toward the East. 